\title{
OS SISTEMAS ADMINISTRATIVOS, DO IMPÉRIO À PRIMEIRA REPÚBLICA: \\ OS MODELOS DE CONTROLE DE ATOS ADMINISTRATIVOS NO BRASIL INDEPENDENTE
}

\author{
Alfredo de Jesus Dal Molin Flores ${ }^{1}$ \\ Raphael de Barros Petersen²
}

Resumo: Sistemas administrativos podem ser definidos como modelos de controle dos atos administrativos, havendo basicamente o sistema de jurisdição única e o de justiça dual. Na experiência brasileira, houve a adoção dos dois modelos: no Segundo Reinado, o sistema de justiça dual e, na Primeira República, o sistema de jurisdição única. Este artigo tem por objetivo descrever a estrutura desses sistemas e explicar o seu funcionamento, com destaque para os critérios e instrumentos de que se valiam para o controle de legalidade, permitindo uma comparação entre eles e a visualização da função que exerciam no contexto histórico-social sobre o qual atuavam.

Palavras-chave: Sistemas administrativos. Justiça dual e jurisdição única. Segundo Reinado e Primeira República.

\section{THE ADMINISTRATIVE SYSTEMS, FROM THE EMPIRE TO THE FIRST REPUBLIC: THE MODELS OF CONTROL OF ADMINISTRATIVE ACTS IN INDEPENDENT BRAZIL}

Abstract: Administrative systems can be defined as models of control of administrative acts, with basically the system of single jurisdiction and dual justice system. In the Brazilian experience, the two models were adopted: in the Empire, the dual justice system and, in the Republic, the system of unique jurisdiction. The purpose of this article is to describe the structure of these systems and to explain their operation, highlighting the criteria and instruments that were used to control legality, allowing a comparison between them and the visualization of the function they exercised in the historical and social context on which they acted.

Keywords: Administrative systems: dual justice and single jurisdiction: Second Reign. First Republic;

\footnotetext{
${ }^{1}$ Professor da Faculdade de Direito da Universidade Federal do Rio Grande do Sul. Professor Permanente do Programa de PósGraduação em Direito da UFRGS. Doutor em Direito e Filosofia pela Universitat de València/Espanha. email: ajdmf@yahoo.com.br

${ }^{2}$ Mestrando em direito no Programa de Pós-Graduação em Direito da UFRGS. Juiz federal substituto na 4a Região. email: raphaelpetersen@msn.com.
} 


\section{INTRODUÇÃO}

Sistemas administrativos podem ser definidos como modelos de controle dos atos administrativos. Há basicamente duas espécies: o sistema de jurisdição única e o sistema de justiça dual. O critério que os diferencia diz respeito ao órgão ou ao poder competente para a solução de controvérsias entre particulares e administração pública e entre a própria administração. Enquanto que no sistema de jurisdição única a solução dessas controvérsias é atribuída ao Poder Judiciário, no sistema de justiça dual há uma Justiça Administrativa ou contencioso administrativo no âmbito do Poder Executivo. A diferença, a princípio apenas orgânica, relativa ao órgão ou poder que exerce o controle dos atos administrativos, pode, porém, assumir outras particularidades, concernentes à forma como é exercido aquele controle, a profundidade com que são sindicados os atos administrativos, os instrumentos para tanto disponíveis.

Na experiência constitucional-administrativa brasileira, houve a adoção dos dois modelos. Ainda que o sistema de justiça dual não seja exclusivo do Império, tendo também se manifestado no período colonial, este modelo de controle dos atos administrativos encontrou certa estabilidade no Segundo Reinado. Da mesma forma, a despeito do sistema de jurisdição única não ser exclusivo da Primeira República, o estudo desse período é importante, na medida em que constitui o primeiro momento em que são trabalhados conceitos e institutos que se tornaram próprios desse modelo de controle dos atos administrativos no Brasil. A possibilidade de anulação de atos administrativos pelo Poder Judiciário, e a extensão do controle aos atos discricionários já constituem questões objeto de debate na Primeira República.

Além disso, a contraposição desses dois modelos permite visualizar as dificuldades inerentes à transição de um sistema de justiça dual, que operou por quase cinquenta anos, com uma ampla e estável jurisprudência, para um sistema de jurisdição única, que, criado com a Nova República, buscava se desvencilhar do modelo anterior, valendo-se de outros critérios e de outros instrumentos para o controle dos atos administrativos. Nesse contexto, houve a criação em 1894 da Ação de Anulação de Ato Administrativo e, mais tarde, podem ser verificadas tentativas de direcionar para o controle dos atos administrativos a utilização de instrumentos a princípio voltados para outras finalidades, como os interditos possessórios e o habeas corpus.

Num primeiro momento, esse artigo abordará a Justiça Administrativa ou contencioso administrativo no Segundo Reinado, a partir das pesquisas conduzidas pela historiadora Lydia Magalhães Nunes Garner e por José Reinaldo Lima Lopes, além da doutrina da época, com destaque 
para José Antônio Pimenta Bueno. Após a apresentação das linhas gerais desse sistema, em cujo ápice figurava o Conselho de Estado, reinstituído e reorganizado na década de 1840, é abordado o critério que delimitava o âmbito de atuação da Justiça Administrativa referentemente ao controle de legalidade dos atos administrativos. Num segundo momento, as atenções se voltam para a Primeira República, sendo mais ampla a fonte de consulta em relação a esse período. Além da doutrina da época, entre os quais Pedro Lessa, Amaro Cavalcanti, Viveiros de Castro, também houve um maior aprofundamento em torno de casos concretos, mencionados por Leda Boechat Rodrigues ou consultados no antigo periódico ‘O Direito'.

\section{JUSTIÇA ADMINISTRATIVA NO SEGUNDO REINADO (1842-1889)}

No sistema de justiça dual, em oposição ao sistema de justiça única, o controle dos atos administrativos é realizado no âmbito do Poder Executivo, mediante um ou mais órgãos, cujo conjunto é denominado Justiça Administrativa, e segundo um determinado procedimento, chamado contencioso administrativo. $O$ sistema de justiça dual é, pois, também denominado sistema de Justiça Administrativa ou do contencioso administrativo ${ }^{3}$. A justiça dual é geralmente vinculada à experiência francesa, no contexto da Revolução, marcado pela desconfiança com o antigo regime, a que se considerava vinculado o Poder Judiciário. É reconhecida a exigência de que, visando a resguardar a autonomia do Poder Legislativo, os juízes deveriam atuar como "a boca da lei”. Por motivos semelhantes, para que fosse garantida agora a autonomia do Poder Executivo, não poderia o Poder Judiciário jurisdicionar em matéria administrativa ${ }^{4}$. Esse quadro implicava a existência de uma rígida separação de poderes, diferentemente da idéia de uma harmonia entre os poderes. A Lei de 16-24 de agosto de 1790 dispunha em seu art. 13:

As funções judiciárias são distintas e permanecerão sempre separadas das funções administrativas. Não poderão os juízes, sob pena de prevaricação, perturbar de qualquer modo as operações dos corpos administrativos, nem citar diante de si os administradores por motivo das funções que estes exercem (CRETELLA, 1971, p. 36).

\footnotetext{
${ }^{3}$ A expressão justiça administrativa, em comparação simplesmente a contencioso administrativo, pressupõe maior autonomia dos órgãos encarregados do julgamento da matéria administrativa, havendo debates em torno da efetiva existência de uma justiça administrativa no Império brasileiro. Neste artigo, as expressões serão utilizadas alternadamente, como equivalentes.

${ }^{4}$ A manutenção ainda hoje do regime de justiça dual na França se vincula a outros fatores, como a aptidão técnica dos órgãos que formam a Justiça Administrativa.
} 
O sistema francês exerceu grande influência sobre a Justiça Administrativa brasileira durante - Segundo Reinado, sendo possível perguntar-se a respeito de uma possível ocorrência de "transplante" jurídico ${ }^{5}$. Escrevendo naquele período, o Marquês de São Vicente fazia contínuas referências ao modelo francês, afirmado que "o Conselho de Estado de França, mormente no tempo da realeza, fornece um exemplo digno de ser imitado" (PIMENTA BUENO, 1857, p. 291).

Portanto, mesmo que o período colonial tivesse conhecido o sistema de Justiça Administrativa, as referências eram maiores ao sistema francês, o que também ficava evidenciado nas decisões proferidas pelo Conselho de Estado brasileiro. O sistema brasileiro, porém, atuava em outro contexto e respondia a fatores sociais, políticos e econômicos absolutamente diversos. Ainda que tenha recebido influência do sistema francês, a Justiça Administrativa no Segundo Reinado Brasileiro acabou apresentando ou realçando outra função, não exatamente isolar o Poder Judiciário, mas assegurar a estabilidade e a concentração da atividade administrativa no imenso território nacional brasileiro (GARNER, 2002, p. 181 e ss).

\subsection{REINTRODUÇÃO DA JUSTIÇA ADMINISTRATIVA}

A Justiça Administrativa no Brasil não é novidade do Segundo Reinado. O período colonial também conheceu o contencioso administrativo, muito em razão da concentração de funções no Poder Executivo, manifestando-se com maior relevo no Tesouro Geral e Real Erário, a que se vinculava o Conselho da Fazenda. É preciso, porém, acentuar a dificuldade e talvez a impossibilidade de visualizar uma continuidade entre o contencioso administrativo do período colonial e do Segundo Reinado. Ainda que o Primeiro Reinado tenha apresentado o contencioso administrativo em relação a matérias específicas (GARNER, 2002, p. 162-163), é extenso o intervalo temporal entre a Independência e a

\footnotetext{
${ }^{5} \mathrm{Em}$ linhas gerais, o "transplante" jurídico se refere à recepção em determinado sistema jurídico, denominado sistema jurídico receptor, da legislação, doutrina, jurisprudência proveniente de outro sistema, a que se chama sistema jurídico emissor. Para maior aprofundamento: LÓPEZ MEDINA, 2009 e BONILLA MALDONADO, 2009.
} 
reintrodução do contencioso administrativo com a recriação do Conselho de Estado, sem falar da radical distinção entre os respectivos contextos político, social e jurídico.

A reintrodução da Justiça Administrativa durante o Segundo Reinado ocorre com a recriação do Conselho de Estado pela Lei 234, de 23 de novembro 1841. O Conselho de Estado foi inicialmente previsto ${ }^{6}$ na Constituição Imperial de 1824, mas acabou sendo suprimido pelo Ato Adicional de 1834.

A função de Justiça Administrativa, porém, somente veio a ser prevista no Regulamento 124 , de 05 de fevereiro de 1842, que regulamentou a Lei 234 e organizou o Conselho de Estado. No Capítulo III do Regulamento, era prevista a disciplina "dos objetos contenciosos". A reintrodução da Justiça Administrativa no Brasil foi, assim, marcada por uma discussão em torno da sua constitucionalidade. A partir de 1842, é possível, pois, falar em um sistema de Justiça Administrativa amplo e abrangente, que se desenvolveu por quase cinqüenta anos, estabelecendo uma extensa jurisprudência, critérios de competência, de admissão das causas, parâmetros de julgamento (GARNER, 2002, p. 162 e ss).

\subsubsection{O Conselho de Estado como um Supremo Tribunal Administrativo}

À semelhança da instituição francesa, o Conselho de Estado brasileiro funcionava como Supremo Tribunal Administrativo, julgando causas em grau de apelação ou última instância, embora a questão suscite controvérsia ${ }^{7}$. Na primeira instância, atuavam os mais diversos órgãos administrativos, com competência ligada à sua área de atuação administrativa (GARNER, 2002). O sistema era de tal maneira fragmentado em primeira instância que não é possível ou é muito difícil estabelecer uma sistematização. Essa fragmentação somente reforça a importância do Conselho de Estado como órgão de cúpula da Justiça Administrativa, único capaz de assegurar certa uniformidade e estabilidade no contencioso administrativo.

Uma vez proferidas e confirmadas pelo Imperador, as decisões (ou pareceres) do Conselho de Estado tinham força de lei, devendo ser obrigatoriamente observadas pelo corpo administrativo, inclusive pelos Ministros de Estado. Como Supremo Tribunal Administrativo, o Conselho de Estado julgava inclusive os conflitos de atribuição entre o Poder Judiciário e a Justiça Administrativa no que

\footnotetext{
${ }^{6}$ Recordando, o Conselho era composto por doze membros vitalícios no serviço ordinário e doze membros no serviço extraordinário. As suas funções eram bastante abrangentes, indo desde a consulta, passando pela preparação de projetos e regulamentos e chegando até a de Supremo Tribunal no contencioso administrativo. ${ }^{7}$ No sentido de que o Conselho de Estado teria atuado como Supremo Tribunal Administrativo: GARNER, 2002. Em sentido contrário: LOPES, 2010.
}

Revista Brasileira de História do Direito | e-ISSN: 2526-009X| Porto Alegre | v. 4 | n. 2 |

p. 75- 92| Jul/Dez. 2018 
diz respeito a matérias administrativas, conforme o Regulamento 124, de 05 de fevereiro de 1842. É possível, assim, afirmar a proeminência da Justiça Administrativa frente ao Poder Judiciário, já que a delimitação das atribuições entre as duas esferas ficava a cargo do Conselho de Estado, panorama que será alterado na Primeira República.

Na França, a concentração do julgamento da matéria administrativa no Conselho de Estado foi um dos fatores responsáveis pela teorização e desenvolvimento de diversos institutos e conceitos de Direito Administrativo e inclusive pela própria autonomia do Direito Administrativa como disciplina (CRETELLA, 1971, p. 38). Basta lembrar da Teoria da Imprevisão e da Teoria do Desvio do Poder, usualmente referidas a decisões do Conselho de Estado. Quanto à Teoria da Imprevisão, é lembrado, entre outros precedentes, o caso Gaz de Bordeaux, de 1916 (BANDEIRA DE MELLO, 2012, p. 664); já a Teoria do Desvio de Poder é vinculada a uma decisão de 1864, confirmada em 1865, relativa ao caso Lesbats (TÁCITO, 1974, p. 05). Há necessidade de ser melhor explorada a contribuição do Conselho de Estado brasileiro para a prática do Direito Administrativo em nosso país. Um período de quase cinco décadas de atuação exclusiva em matéria administrativa certamente não passou sem deixar suas marcas.

\subsection{ADMINISTRAÇÃO GRACIOSA E JUSTIÇA ADMINISTRATIVA}

No período imperial, a administração pública, como parte do Poder Executivo, era usualmente distinguida em administração graciosa (ou administração simples, pura ou discricionária) e Justiça Administrativa (ou contencioso administrativo ou administração contenciosa). A administração graciosa lidava com interesses, coletivos e individuais, atuando de modo discricionário, com base em razões de conveniência e oportunidade. A discricionariedade era também concebida como "discrição ilustrada". A administração graciosa dizia, assim, preponderantemente respeito a questões como relações exteriores, segurança interna e externa, políticas públicas nas mais diversas áreas, devendo, nesse âmbito, o interesse particular ceder ao interesse geral. Na administração graciosa, era constante a menção a interesses, especialmente coletivos e gerais; direitos individuais não eram mencionados, ao passo que direitos sociais ou coletivos sequer eram concebidos naquela época (PIMENTA BUENO, 1857 , p. 291 e ss).

Em face da administração graciosa, não podia o particular exigir uma tomada de posição ou, em outras palavras, litigar contra a administração, podendo, no máximo, apresentar um recurso gracioso, em relação ao qual não havia qualquer obrigação de resposta. Na Justiça Administrativa ocorria exatamente o contrário: ela não lidava com interesses, gerais ou coletivos, não atuava com 


\section{OS SISTEMAS ADMINISTRATIVOS, DO IMPÉRIO À PRIMEIRA REPÚBLICA: OS MODELOS DE CONTROLE DE ATOS ADMINISTRATIVOS NO BRASIL INDEPENDENTE}

base em um juízo de discricionariedade ou "discrição ilustrada", em que o interesse particular deveria ceder ao interesse geral, mas operava somente em face de direitos individuais, previstos na legislação, no regulamento ou em contrato administrativo, cuja violação (ou alegação de violação) impunha à administração uma obrigação de resposta. A distinção entre administração graciosa e Justiça Administrativa, portanto, não era propriamente rationae materiæ, mas de perspectiva, dependendo se a atuação administrativa, independentemente da área, pudesse ou não afetar direitos individuais.

\subsubsection{Interesse e direito individual: competência do contencioso administrativo}

Como se pode ver, as categorias jurídicas 'interesse' e 'direito individual' exerciam importante função no âmbito do contencioso administrativo. Se o mero interesse suscitava tão-somente o uso do recurso gracioso, a que a administração poderia deixar de responder ou responder conforme a sua conveniência, a violação do direito individual viabiliza o acionamento do contencioso administrativo. Lydia Garner menciona algumas situações em que não se admitiu o ingresso no contencioso administrativo, entre as quais aquela em que:

o apelo de Antônio José da Silva Travassos contra decisão do Ministro da Agricultura que negou privilégio para navegação dos rios Possonga e Japaratuba foi recusado pela Seção do Império porque 'o assunto de (concessão) de privilégio não pertencia ao contencioso mas sim ao gracioso' e que se causava dano aos interesses de Travassos, não violava nenhum de seus direitos (GARNER, 2002, p. 171).

É interesse notar, como já referido, a vinculação entre direito (subjetivo) e esfera individual: o direito era, pois, o direito individual. Além disso, o direito individual somente podia ser visualizado como tal se expressamente previsto na legislação, no regulamento ou no contrato. Como o acionamento da Justiça Administrativa dependia da violação de um direito individual, que somente era assim reconhecido se expressamente previsto em lei, regulamento ou contrato, o controle dos atos administrativos assumia contornos de estrita legalidade. Para que se tenha dimensão do exercício desse controle, são novamente destacados alguns casos trazidos pela historiadora Lydia Garner (2002, p. 169):

Saúde Pública era outra área sob a jurisdição do Ministério do Império que também apelava em última instância para a Seção do Império. Esta área estava melhor 
organizada do que a de Instrução, pois contava com a Junta Central de Saúde Pública, a Inspeção Pública, e o Instituto Vacínico. A Junta tinha autoridade para impor penas, suspensões, ou encarceramento por infrações cometidas contra as suas regras, mas suas decisões podiam ser apeladas para a Seção do Império. Em 1886 F. Sauven \& Cia. apelou de decisão da Divisão de Inspeção de Saúde contra a venda de itens estragados em sua loja (NA, C.561, P.1, D 4) e João de Deus da Cunha Pinto apelou a decisão da Divisão de fechar a Clínica Santa Teresa (NA, C.561, P.1, D.5)

\section{CONTROLE JURISDICIONAL DOS ATOS ADMINISTRATIVOS NA PRIMEIRA REPÚBLICA (1889-1930)}

Menos de dois anos após o 15 de novembro, é promulgada, em 24 de fevereiro de 1891, a primeira constituição republicana brasileira: a Constituição dos Estados Unidos do Brasil. Era natural que não se fosse buscar no Império a inspiração para o desenho institucional da Primeira República. Pedro Lessa, escrevendo na década de 1910, referia que o Brasil havia sido um dos "países que lhes [aos Estados Unidos da América] imitaram as instituições" (LESSA, 1915, p. 55), o que podia ser visto em diversas passagens da Constituição de 1891: regime republicano, forma federativa de Estado, presidencialismo, organização do Poder Judiciário ${ }^{8}$. Vários questionamentos jurídicos se colocavam em face da ordem política recém instaurada. Um deles era saber se subsistia o Sistema de Jurisdição Dúplice até então vigente ou se, pelo contrário, passara o Brasil a adotar o Sistema de Jurisdição Única.

A Constituição de 1891 não fez referência ao Conselho de Estado, o que poderia ser interpretado no sentido da abolição do contencioso administrativo. Mais importante nesse aspecto era, porém, o art. 60, b, da Constituição, cometendo à Justiça Federal a competência para o julgamento de "todas as causas propostas contra o Governo da União ou Fazenda Nacional, fundadas em disposições da Constituição, leis e regulamentos do Poder Executivo, ou em contratos celebrados com o mesmo Governo". Pela abrangência do dispositivo, competia ao Poder Judiciário, e não à administração, a apreciação de toda e qualquer causa que envolvesse o poder público. Pedro Lessa (1915, p. 143 e ss), importante nome da doutrina na época, afirmava que a tendência era o reconhecimento da existência do Sistema de Jurisdição Una. Um breve exame da jurisprudência do Supremo Tribunal Federal na época revela o julgamento de diversas causas de Direito Público, não

\footnotetext{
${ }^{8}$ Não pode ser ignorada a influência do direito argentino na conformação da Constituição da 1891, conforme destacado por LYNCH, 2004, p. 101.
}

Revista Brasileira de História do Direito | e-ISSN: 2526-009X| Porto Alegre | v. 4 | n. 2 |

p. 75- 92 | Jul/Dez. 2018 
deixando dúvida a respeito da efetiva observância do princípio da unicidade da jurisdição (RODRIGUES, 1991, passim)

\section{1 ÂMBITO DE ATUAÇÃO DO CONTROLE JURISDICIONAL: QUESTÕES POLÍTICAS E QUESTÕES JUDICIAIS}

Com a abolição do contencioso administrativo pela Constituição de 1891, diversas questões de Direito Público e Direito Administrativo passam a ser submetidas ao Poder Judiciário e mais especificamente ao Supremo Tribunal Federal, instituição criada no regime republicano pelo Decreto 848 , de 11 de outubro de 1890 . Foi o Supremo provocado a se manifestar a respeito de atos praticados pelo Poder Executivo na vigência de estado de sítio, dos limites da intervenção do Estado em saúde pública, da demissão de professores, da reforma de militares, dos limites entre Estados-membros da federação (RODRIGUES, 1991, passim). No exame dessas delicadas questões político-institucionais, o Supremo Tribunal Federal construía o seu espaço de poder e o seu papel frente à sociedade e aos demais poderes.

O Supremo Tribunal Federal era, todavia, uma instituição nova e dificilmente poderia observar, para delimitar o seu campo de atuação, a jurisprudência do Conselho de Estado durante o Segundo Reinado. O sentimento da época não era definitivamente o de se valer da experiência das instituições imperiais, mas a de buscar um paralelo em outras repúblicas federativas. A Constituição de 1891, ao adotar o regime republicano federalista, teve como inspiração a Constituição Norte-Americana; era natural, na mesma linha, que o Supremo Tribunal Federal também considerasse a experiência da Suprema Corte daquele país. Em inúmeros acórdãos do Supremo Tribunal Federal no período da Primeira República, era contínua a referência à jurisprudência da Suprema Corte Norte-Americana, sendo, pelo contrário, raríssimas as menções a precedentes de Tribunais do período imperial (RODRIGUES, 1991, passim). Para construir o seu campo de atuação e desenhar o seu papel frente à sociedade e aos demais poderes, o Supremo Tribunal Federal se valeu, entre outras categorias jurídicas, da doctrine of political questions utilizada pela Suprema Corte norte-americana.

Pedro Lessa, que foi Ministro do Supremo Tribunal Federal na Primeira República, definia questões políticas e questões judiciais a partir de Rui Barbosa, o qual, por sua vez, se baseava na jurisprudência da Suprema Corte e na doutrina dos constitucionalistas Norte-Americanos, como Thayer, Story, Pomeroy, Bryce. As questões políticas seriam infensas à apreciação do Poder Judiciário,

\footnotetext{
${ }^{9}$ Não se pode deixar de ressaltar a existência de exceções no plano da legislação infraconstitucional, a começar pelo Decreto 392, de 08 de outubro de 1896, que estabelecia o funcionamento do Tribunal de Contas como "Tribunal de Justiça com jurisdicção contenciosa e graciosa".
} 
diferentemente das questões judiciais, que constituem o seu natural campo de atuação. A definição da questão como política ou judicial é, porém, realizada pelo próprio Poder Judiciário, que, assim, possui certa margem de discricionariedade na delimitação da extensão da sua intervenção. Dependendo da questão ou do momento histórico, pode haver uma decisão pela intervenção, rotulando a questão como judicial, ou pela não intervenção, em razão do caráter político da questão (LESSA, 1914, p. 54 e ss).

Embora a doctrine of political questions fosse construída e operasse de maneira casuística, Pedro Lessa traça as linhas gerais para a definição de uma questão como política ou judicial. A questão política, infensa à apreciação do Poder Judiciário, é a questão puramente política. A mera presença de aspectos políticos em torno de uma questão não implica o seu afastamento do âmbito jurisdicional. Como questão puramente política, deve ser compreendida aquela a que não corresponde um direito individual. A questão política, uma vez despida de qualquer vínculo a um direito individual, assume a feição de um "poder meramente político ou discricionário", dizendo respeito ao "interesse comum, utilidade pública, necessidade, vantagem nacional”, a exemplo das relações diplomáticas, da declaração da guerra e da paz, do comando das forças armadas, das relações com tribos indígenas, do provimento de cargos federais, das rendas públicas. O controle das questões políticas não é tarefa do Poder Judiciário, devendo ser relegada aos "freios da opinião popular e moral social" (LESSA, 1914, p. 63).

A questão judicial, por sua vez, é definida por oposição à questão política: questão judicial é aquela a que corresponde um direito individual, do que decorre a imposição de um dever para a administração pública. Não há, nesse campo, discricionariedade por parte da administração, cuja ação deve se pautar pelo dever decorrente do direito individual violado ou cuja violação esteja ameaçada (LESSA, 1914, p. 54 e ss) interessante notar a ausência de menção, para a definição da questão judicial, de direitos coletivos ou difusos, vistos como meros interesses e, portanto, necessariamente como questões políticas. O Poder Judiciário, de fato, era destinado, ainda segundo Pedro Lessa, à "aplicação do Direito legal aos casos particulares"; o "Poder Judiciário só se pronuncia acerca de casos particulares, e não em abstrato sobre normas, ou preceitos jurídicos, e ainda menos sobre princípios" (LESSA, 1914, p. 01).

\subsection{INSTRUMENTOS PARA O CONTROLE JURISDICIONAL DOS ATOS ADMINISTRATIVOS}

No Segundo Reinado havia, conforme Lydia Garner, um sistema de contencioso administrativo bem desenvolvido, com uma extensa jurisprudência. A Proclamação da República extingue a Justiça 
Administrativa, atribuindo ao Poder Judiciário o julgamento de causas envolvendo a administração pública. O Poder Judiciário não possuía, porém, experiência institucional nesse campo: mediante quais instrumentos ocorreria o controle jurisdicional dos atos administrativos? Como esse controle seria exercido? A partir de que critérios? Qual a extensão e profundidade do controle? Em relação a muitas dessas perguntas, o Supremo Tribunal Federal iria utilizar a experiência da Suprema Corte NorteAmericana, a exemplo das já mencionadas questões políticas e judiciais, que permitiam definir os limites do controle jurisdicional dos atos do Poder Público.

No entanto, relativamente aos instrumentos para o exercício desse controle, o sistema brasileiro adotou em muitas situações soluções originais, como a Ação Anulatória de Atos Administrativos, criada pela Lei 221, de 20 de novembro de 1894, e o alargamento das hipóteses a priori de cabimento dos interditos possessórios e do habeas corpus. Ainda que a historiografia do Supremo Tribunal Federal usualmente realce o papel desempenhado pelo habeas corpus, inclusive cunhando o alargamento da suas hipóteses de cabimento como a 'doutrina brasileira do habeas corpus' (VELLOSO, p. 173/191), a Ação Anulatória de Atos Administrativos e especialmente os interditos possessórios merecem maior atenção.

\subsubsection{Ação de Anulação de Ato Administrativo}

A Ação de Anulação de Ato Administrativo foi instituída pelo art. 13 da Lei 221, de 20 de novembro de 1894. Antes da sua introdução, não havia instrumento que permitisse a anulação de atos administrativos pelo Poder Judiciário, tendo a atribuição dessa competência suscitado a crítica da doutrina da época. Viveiros de Castro (1914, p. 682) referia que "a doutrina jurídica condemna formalmente essa competência conferida ao Poder Judiciário para anullar actos administrativos". Em razão do princípio da separação dos poderes, prossegue Viveiros de Castro citando Thonissen, poderiam os tribunais "recusar á applicação de acto administrativo illegal", mas "elles não tem o direito de modificar ou abrogar este acto" (1914, p. 682). A introdução do art. 13, com a redação que Ihe foi conferida, teria ocorrido por acidente, já que a expectativa seria a supressão ou a modificação de algumas das suas disposições. Conforme ainda o relato de Viveiros de Castro:

O meu saudoso amigo Dr. Amphilophio também me contou que interpellando o Dr.
José Hygino, ao regressar duma viagem á Europa, sobre a singularidade de algumas
das disposições do alludido art. 13 de sua autoria, ele confessára que o dito artigo
excedera de muito o seu objectivo: mas que, contando com forte opposição

Revista Brasileira de História do Direito | e-ISSN: 2526-009X| Porto Alegre | v. 4 | n. 2 |

p. 75- 92| Jul/Dez. 2018 
governamental e larga discussão no Congresso Nacional, entendêra conveniente deixar margem para emendas; e que, attrahida a atenção dos adversários para os exaggeros da medida proposta, seria possível salvar alguma cousa de útil.

Conseguintemente, alguns dos parágraphos do citado art. 13 eram carga destinada a ser atirada ao mar na occasião da tempestade (1941, p. 680). A Ação de Anulação de Ato Administrativo abrangia inclusive "a medida administrativa tomada em virtude de uma faculdade ou poder discricionário". Neste caso, porém, a anulação exigia a demonstração "da incompetência da autoridade respectiva" ou "do excesso de poder" (art. 13, §9, b). Esse dispositivo suscitava ainda maiores críticas, porque diria respeito apenas a "interesses", e não direitos. O binômio interessedireito, que demarcava o âmbito de atuação do contencioso administrativo durante o Segundo Reinado, reaparece, portanto, como justificativa para afastar o controle jurisdicional dos atos administrativos discricionários. Viveiros de Castro refere inclusive julgamento do Supremo Tribunal Federal de 23 de agosto de 1899 em que se reconheceu a inconstitucionalidade do §9 do art. 13 da Lei 221 (1914, p. 684).

Era admitida a suspensão liminar do ato administrativo, nos termos do §70 do art. 13: "a requerimento do autor a autoridade administrativa, que expediu o acto ou medida em questão, suspenderá a sua execução, si a isso não se oppuzerem razões de ordem pública". Em que pese a possibilidade de anulação dos atos administrativos e inclusive a sua liminar suspensão, Alfredo Buzaid $(1956$, p. 07) ressaltava que "muito cedo [...] se desvaneceram as esperanças despertadas na lei". Isso teria ocorrido em razão "do contraste entre a suspensão imediata do ato e o julgamento demorado do pleito". A Ação de Anulação de Ato Administrativo não se apresentava, pois, como apta a tutelar as necessidades da vida em sociedade. Ainda segundo Alfredo Buzaid, não era possível "impedir a ameaça de violação iminente, ou obter o pronto restabelecimento do direito violado" (1956, p. 07). Essa insuficiência da Ação de Anulação de Atos Administrativos explica, entre outros fatores, a tentativa de ampliação da hipótese a priori de cabimento de outros instrumentos processuais.

\subsubsection{Interditos Possessórios}

Em 1905, Amaro Cavalcanti, que, assim como Pedro Lessa, foi Ministro do Supremo durante a República Velha, colocava a questão nos seguintes termos:

Surge, entretanto, uma questão importantissima: a de saber, si ao lesado por acto da administração publica cabe o direito de requerer remedio judiciario de natureza

Revista Brasileira de História do Direito | e-ISSN: 2526-009X| Porto Alegre | v. 4 | n. 2 |

p. 75- 92 | Jul/Dez. 2018 


\section{OS SISTEMAS ADMINISTRATIVOS, DO IMPÉRIO À PRIMEIRA REPÚBLICA: OS MODELOS DE CONTROLE DE ATOS ADMINISTRATIVOS NO BRASIL INDEPENDENTE}

preventiva, para obstar desde logo o proprio acto ou os seus effeitos immediatos? Ou em termos mais breves, si são admissiveis os interdictos possessorios ou prohibitorios contra os actos administrativos (1905, p. 566).

Viveiros de Castro (1914, p. 685 e ss) resume as duas posições de maneira geral. A negativa da utilização dos interditos possessórios estava fundada no Direito Romano, que não admitia a posse sobre direitos pessoais, e numa interpretação restritiva do Livro 3, tit. 78, §5ํㅡ, das Ordenações. Entre os defensores dessa posição se encontrava o já mencionado Amaro Cavalcanti. A admissibilidade da utilização dos interditos, por outro lado, se justificava no direito canônico, que adotava posição contrária ao Direito Romano, na opinião de antigos praxistas portugueses e numa interpretação ampliativa do dispositivo das Ordenações. Nesse outro lado da discussão era destacado o papel exercido por Rui Barbosa.

O importante, porém, é ressaltar que não se tratava de uma questão meramente teórica, de interesse puramente jurídico. Significava amparar ou deixar de amparar, intervir ou deixar de intervir em situações marcadas pela relação administração-administrado, ampliando ou restringindo o controle jurisdicional dos atos administrativos. Em termos teóricos, a solução da questão passava por definir se a posse poderia, além das coisas corpóreas, abranger também os direitos pessoais. Mas em termos práticos, conduzia aos seguintes questionamentos: poderiam os interditos possessórios ser utilizadas para obstar a cobrança de impostos, garantir o direito a vender mercadorias sem inspeção pelas autoridades sanitárias, impedir a fiscalização das autoridades sanitárias na residência dos administrados?

No início do Século XX, era grande a preocupação com a saúde pública, especialmente no Rio de Janeiro, cuja população vinha aumentando progressivamente, de maneira desordenada e sem controle sanitário. Rodrigues Alves (1902-1906) promove, com o apoio de Oswaldo Cruz, campanha pelo saneamento do RJ, contra a febre amarela, a varíola e a peste bubônica. A campanha envolve o ingresso e a vistoria de residências particulares pelas autoridades sanitárias, com especial atenção para os cortiços, bastante comuns na época e que abrigavam a população menos favorecida economicamente. Ao mesmo tempo, o Prefeito Pereira Passos comanda a modernização do Rio de Janeiro, com o alargamento de suas ruas, ocasionando a remoção de muitas famílias, medida que acaba atingindo novamente os cortiços e a população menos favorecida. Esses fatores, aliados a outros, como a imposição da vacina obrigatória, iriam desencadear a Revolta da Vacina (CARVALO, 1987, cap. IV). 
Para o sucesso da política de higienização e modernização do Rio de Janeiro, havia, como afirmado, a necessidade de viabilizar o ingresso das autoridades sanitárias nas residências particulares. Em face da ausência, como destacado por Alfredo Buzaid, de medidas liminares no rito da Ação de Anulação de Ato Administrativo, disciplinada pela Lei 221, de 1894, o instrumento processual que poderia impedir aquele ingresso seria o interdito possessório. Em 1900 já há o registro de interditos possessórios impetrados em face de atos praticados por autoridades sanitárias, ainda que tenha o Supremo Tribunal Federal se manifestado contrariamente à possibilidade, "porquanto contra os atos da administração pública, no exercício legítimo de suas atribuições de polícia, não são cabíveis interditos possessórios que suspendam ou anulem tais atos" (RODRIGUES, 1991, v. 02, p. 77,). O fato é que havia a impetração de interditos possessórios contra atos praticados por autoridades sanitárias e, a despeito da jurisprudência do STF, não era possível descartar a priori o risco de concessão da medida no primeiro grau de jurisdição, decisão cuja reversão necessariamente exigira certo período de tempo.

A Lei no 939, de 29 de dezembro de 1902, reorganizou o Distrito Federal. O seu art. 16 previa claramente uma limitação ao controle dos atos administrativos, inclusive mediante interditos possessórios: "não podem as autoridades judiciarias, quer federaes, quer locaes, modificar ou revogar as medidas e actos administrativos, nem conceder interdictos possessorios contra actos do Governo Municipal exercidos ratione imperii". A limitação estava, portanto, vinculada aos atos de império, o que abria margem a interpretação. O decreto no 1.151, de 5 de janeiro de 1904, foi mais específico em relação à questão sanitária. 0 decreto visava reorganizar "os serviços da hygiene administrativa da União", criava no Distrito Federal o "juizo dos feitos da saúde publica", com ampla competência em matéria sanitária, e estabelecia uma vedação a esse juízo e outras autoridades judiciais relativamente aos interditos possessórios, de modo semelhante à prevista na Lei 939. Dispunha o decreto: "não podem a justiça sanitaria, nem as autoridades judiciarias, quer federaes, quer locaes, conceder interdictos possessorios contra os actos da autoridade sanitaria exercidos ratione imperii, nem modificar ou revogar os actos administrativos ou medidas de hygiene e salubridade por ella determinadas nesta mesma qualidade (art. 1ㅇ, §20)".

Embora a questão exija maior aprofundamento, não se pode descartar eventual relação entre a restrição dos instrumentos para o controle dos atos tomados pela vigilância sanitária e a eclosão ou pelo menos os eventos que a precederam - da Revolta da Vacina, expressão da insatisfação popular com a política pública sanitária. 


\subsubsection{Habeas corpus}

Em face da insuficiência da Ação de Anulação de Ato Administrativo, derivada da incapacidade de inibir a prática de atos ilícitos ou obter desde logo a satisfação do direito, e também em razão da resistência a uma maior utilização dos interditos possessórios, outra alternativa para a efetivação do controle jurisdicional dos atos administrativos residia no habeas corpus. A despeito de tradicionalmente voltado para a tutela da liberdade de locomoção, de ir, vir e ficar, o art. 72, §22으, da Constituição de 1891, na sua redação original, previa o habeas corpus da seguinte maneira: "dar-se-á o habeas corpus, sempre que o indivíduo sofrer ou se achar em iminente perigo de sofrer violência ou coação por ilegalidade ou abuso de poder". Não havia, portanto, menção a liberdade de locomoção, mas apenas a "violação ou coação por ilegalidade ou abuso de poder".

Assim, Andrei Koerner, após examinar uma série de habeas corpus julgados durante a Primeira República, afirma não ser possível reconhecer um "corpo homogêneo, a partir do qual possamos tirar conclusões sobre um doutrina jurídica do habeas corpus que predominou no STF na Primeira República" (2014, p. 78). Além disso, ao contrário do que resultaria da conhecida 'doutrina brasileira do habeas corpus', não seria possível visualizar, ainda segundo o autor, "uma evolução jurisprudencial do habeas corpus no STF, nem do seu conteúdo, no sentido da afirmação ou negação da garantia judicial de determinados direitos civis" (2014, p. 25).

De qualquer forma, sem entrar no mérito da discussão mais ampla a respeito da existência da denominada "doutrina brasileira do habeas corpus" no âmbito do STF, caracterizada pela ampliação da sua hipótese de cabimento, o fato é que em muitas situações houve a impetração de habeas corpus para o controle dos atos administrativos. São conhecidos os diversos habeas corpus no âmbito de conflitos eleitorais estaduais, como narrado pelo próprio Koerner (2010, p. 184 e ss), em face do resultado de eleições, da dualidade de Assembléias Legislativas, de atos praticados durante intervenções federais e estados de sítio. Esse uso do habeas corpus somente era possível em razão da redação do art. 72, §22으, da Constituição de 1891, que não fazia menção a liberdade de locomoção.

\subsubsection{Reforma Constitucional de 1926 e criação do Mandado de Segurança em 1934}

A Reforma Constitucional de 1926, promovida pela Emenda Constitucional n.ㅇ 3, previu importantes limitações ao Poder Judiciário. Além da introdução do §5o ao art. 60 da Constituição, impondo ou confirmando restrições ao controle jurisdicional de diversos atos, entre os quais os praticados durante a vigência de estado de sítio, houve a alteração da redação do $\$ 22^{\circ}$ do art. 72 da 
Constituição de 1891, que previa o habeas corpus. A alteração, sutil e pontual, tinha grandes conseqüências: houve o acréscimo da expressão "liberdade de locomoção" ao final do dispositivo: "dar-se-ha o habeas-corpus sempre que alguém soffrer ou se achar em imminente perigo de soffrer violencia por meio de prisão ou constrangimento illegal em sua liberdade de locomoção". Era colocado, assim, um entrave a um possível instrumento de controle jurisdicional dos atos administrativos.

O sistema de controle jurisdicional dos atos administrativos encontraria certa estabilidade, pelo menos no plano normativo, com a criação do mandado de segurança pela Constituição de 1934. A redação do art. 113, n. 33, que instituiu o mandado de segurança, é indicativa dos seus antecedentes: “dar-se-á mandado de segurança para defesa do direito, certo e incontestável, ameaçado ou violado por ato manifestamente inconstitucional ou ilegal de qualquer autoridade. 0 processo será o mesmo do habeas corpus, devendo ser sempre ouvida a pessoa de direito público interessada. O mandado não prejudica as ações petitórias competentes".

Há, portanto, expressa menção ao habeas corpus, cujo procedimento deveria o mandado de segurança observar. A menção a "ato manifestamente inconstitucional ou ilegal de qualquer autoridade" não deixa de lembrar o $\$ 10$ do art. 13 da Lei 221, de 20 de novembro de 1894, que permitia aos juízes deixar de "applicar aos casos occurrentes as leis manifestamente inconstitucionaes e os regulamentos manifestamente incompativeis com as leis ou com a Constituição". Por fim, poderia parecer estranho estabelecer que "o mandado não prejudica as ações petitórias competentes", não fosse o fato de que o mandado de segurança, da maneira como previsto, substituiria em muitas situações as ações possessórias, as quais, como se sabe, são independentes das ações petitórias. Ainda, portanto, que não tenha havido expressa intenção, não há como negar a influência sobre a redação do mandado de segurança dos institutos anteriormente utilizados para o controle jurisdicional dos atos administrativos.

\section{CONSIDERAÇÕES FINAIS}

Tanto o sistema de justiça dual do Segundo Reinado como o de jurisdição única da Primeira República realizavam o controle dos atos administrativos. No entanto, o modo e os critérios de exercício desse controle eram diversos, evidenciando o caráter histórico e social do Direito, que é organizado em referência ao contexto sobre o qual atua, sendo influenciado e influenciando esse mesmo contexto. Além de estarem estruturados de maneira diversa, os sistemas não apresentavam a mesma função social, a despeito da identidade de função jurídica. 


\section{OS SISTEMAS ADMINISTRATIVOS, DO IMPÉRIO À PRIMEIRA REPÚBLICA: OS MODELOS DE CONTROLE DE ATOS ADMINISTRATIVOS NO BRASIL INDEPENDENTE}

O sistema de Justiça Administrativa do Segundo Reinado, de inspiração francesa, era integrado ao Poder Executivo e tinha como órgão de cúpula o Conselho de Estado. O binômio interesse/direito individual demarcava o âmbito de atuação do controle de legalidade, que somente se referia a situações em que houvesse a violação de um direito individual, assim reconhecido se expressamente previsto em lei, regulamento ou contrato. O mero interesse, individual ou coletivo, era relegado à administração graciosa, que não possuía o dever de decidir, deliberando com base na sua discricionariedade. $O$ contencioso administrativo no Segundo Reinado perdurou por quase cinquenta anos, resultando no desenvolvimento de uma ampla jurisprudência, com critérios e parâmetros de controle.

Na Primeira República, com a extinção da Justiça Administrativa, o controle de legalidade dos atos administrativos foi atribuído ao Poder Judiciário, com destaque para o Supremo Tribunal Federal. O sistema de jurisdição única tinha inspiração norte-americana, sendo que o controle de legalidade era demarcado pelo binômio questões políticas/questões jurídicas. As questões exclusivamente políticas, a que não correspondiam um direito individual, não poderiam ser objeto de controle por parte do Poder Judiciário, devendo ser relegadas aos "freios da opinião pública". Houve dificuldade em estabelecer os instrumentos adequados para o exercício do controle de legalidade, muito provavelmente em razão da ausência de maior experiência institucional por parte do Poder Judiciário.

\section{REFERÊNCIAS BIBLIOGRÁFICAS}

BANDEIRA DE MELLO, Celso Antônio. Curso de Direito Administrativo. 29a edição. São Paulo: Malheiros, 2012

BARBI, Celso Agrícola. Do mandado de segurança. 11ạ. ed. rev. Rio de Janeiro: Forense, 2008.

BONILLA MALDONADO, Daniel. Introducción. Teoría del derecho y trasplantes jurídicos: la estructura del debate. In: BONILLA MALDONADO, Daniel (org). Teoría del derecho y trasplantes jurídicos. Bogotá: Siglo del Hombre Editores, Univ. De los Andes, Pontificia Universidad Javeriana, 2009.

BUZAID, Alfredo. Do mandado de segurança. Revista Forense, vol. 164, 1956.

CARVALHO, José Murilo de. Os bestializados: o Rio de Janeiro e a República que não foi. São Paulo: Companhia da Letras, 1987.

CAVALCANTI, Amaro. Responsabilidade Civil do Estado. Rio de Janeiro: Lammert \& C., 1905.

CRETELLA, Júnior. O contencioso administrativo na Constituição de 1969. Revista de Direito Administrativo. Rio de Janeiro, v. 104, p. 30-48, 1971.

FREITAS, Juarez. $O$ controle dos atos administrativos e os princípios fundamentais. São Paulo: Malheiros, 2013. 
GARNER, Lydia Magalhães Nunes. Justiça Administrativa no Brasil do Segundo Reinado (1842-1889). Revista de História da USP, n. 147, p. 159/188, 2002.

KOERNER, Andrei. Judiciário e cidadania na Constituição da República brasileira (1841-1920). 2ª ed. Curitiba: Juruá, 2010.

KOERNER, Andrei. O Habeas Corpus na Prática Judicial Republicana: o problema dos direitos civis. In: FLORES, Alfredo de J. (org.). Temas de história do direito: o Brasil e o Rio Grande do Sul na construção dos Conceitos Jurídicos Republicanos (1889-1945). Porto Alegre: Instituto Histórico e Geográfico do Rio Grande do Sul, 2014, p. 11-84.

LESSA, Pedro. Do Poder Judiciário. Rio de Janeiro: Liv. Francisco Alves, 1915.

LÓPEZ MEDINA, Diego E. La cartografía de la teoría jurídica. Diálogo con los críticos. In: BONILLA MALDONADO, Daniel (org.). Teoría del derecho y trasplantes jurídicos. Bogotá: Siglo del Hombre Editores, Universidad de los Andes, Pontificia Universidad Javeriana, 2009. p. 177-215;

LYNCH, Christian Edward Cyril. Da monarquia à oligarquia: história institucional e pensamento político brasileiro (1822-1930). São Paulo: Alameda, 2014.

PIMENTA BUENO, José Antônio. Direito Público Brasileiro e Analyse da constituição do Império. Rio de Janeiro. Typographia Imp. E Const. De J. Villeneuve E C., 1857.

RODRIGUES, Leda Boechat. História do Supremo Tribunal Federal. Tomo I, 1891 1898: defesa das liberdades civis. Rio de Janeiro Civilização Brasileira, 1991.

RODRIGUES, Leda Boechat. História do Supremo Tribunal Federal. Tomo II, 1889-1910: defesa da federação. Rio de Janeiro: Civilização Brasileira, 1991.

TÁCITO, Caio. Teoria e prática do desvio de poder. Rio de Janeiro. Revista de Direito Administrativo, 117, p. 01-18, 1974.

VELLOSO, Carlos Mário da Silva. Pedro Lessa e a teoria brasileira do 'habeas corpus'. In: Revista da Academia Brasileira de Letras Jurídicas, v. 26, p. 173-191.

VIVEIROS DE CASTRO, Augusto Olympio. Tratado de sciencia da administração e direito administrativo. Rio de Janeiro: Jacintho Ribeiro dos Santos Livreiro-editor, 1914. 